\title{
Sundanese Bridal Makeup Guideline in Art Education Perspective
}

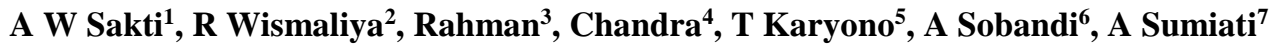 \\ $\left\{\right.$ 1 achiewibawasakti@gmail.com, ${ }^{2}$ wismaliyarisa@gmail.com, ${ }^{3}$ rahmanprofupi@upi.edu, \\ ${ }^{4}$ chandra@upi.edu, ${ }^{5}$ tri3karyono@gmail.com, ${ }^{6}$ ade@ upi.edu, ${ }^{7}$ aisumiati1960@ gmail.com\} \\ 1,2,3,5,6 Universitas Pendidikan Indonesia Bandung, Indonesia \\ ${ }^{4}$ Universitas Negeri Padang, Indonesia \\ ${ }^{7}$ Sukabumi Regency Education Office, Indonesia
}

\begin{abstract}
The Sundanese have special characteristics in managing bridal makeup. Many Sundanese people do not know the complete guidelines on how to arrange makeup for Sundanese brides. This article aims to obtain a comprehensive picture of the Sundanese bridal makeup guidelines in the perspective of art education. The study was conducted using qualitative methods. The qualitative method was applied in this study with a descriptive approach. The results of the research that have been done show that there are complete descriptors about art education in all elements of Sundanese bridal makeup which are little known by the Sundanese themselves. There is a need for efforts to preserve Sundanese cosmetology culture by the community and the government.
\end{abstract}

Keywords: Makeup Guideline, Sundanese Bridal, Art Education

\section{INTRODUCTION}

Every human being has an important moment in their life such as wedding. Marriage is sacred to some people or a group of people even for Sundanese people. Sundanese people have their own traditions and bridal makeup guideline especially the bride. The bride and groom will be limelight in the wedding procession where all guests will pay attention to the bride from their makeup, hair and clothing [1]-[3].

Makeup is an art system that is one of the universal cultures, namely as the art system that used to express themselves to beauty [4], [5]. Makeup has many types, such as makeup, corrective makeup, make-up for art and others. Andiyanto argued that makeup's function is as the power to change the face more glow and look special by still paying attention to personal natural beauty [6], [7]. According to make up is essentially included in the material culture section which "refers to all real, concrete society creations" [8], [9]. Therefore, do not be surprised if the Sundanese bridal makeup is closely related to Sundanese society's culture.

Everything the bride wears has the meaning and art value in it. According to Desiana argued that Sundanese siger makeup hass sacred beauty that contains noble cultural values [10], [11]. Sundanese bride has its own guidline for their makeup on the head until the special shoes used, even for the groom. Although the bride wears more special accessories for the bride, the groom wears several accessories that have meaning. In a traditional bridal makeup, it is usually formed on the cultural basis, legends and myths prevailing in the area, and the historical conditions of 
the people. It is considering that basically bridal makeup is a form of culture based on ideas, ideas and philosophy applied in human work [12], [13].

In addition, the bridal makeup must have a beautiful element of art. Makeup settings on brides are using cosmetics and certain techniques. It aims to change in the direction to do it (in no hurry) so that the makeup produced is as expected [14], [15]. As makeup in the most regions of Indonesia, the Sundanese bridal makeup also has Sundanese identity. It is used as identification because it has meaning in the culture that is created by the society, so that it can be distinguished between one culture and another culture. If we want to know and apply cultural identity, we do not only determine the characteristics, physical or biological characteristics, but also examine the cultural identity of a group of people through order (thinking, thinking orientation), feeling (feeling and its orientation), and how to act (motivational action or action orientation) [16], [17].

In this study, the guidline meant in Sundanese bridal makeup is to discuss makeup and accessories that is worn by the brides both of the bride and groom that has art and meaning. It cannot be underestimated because it has cultural value that is upheld and also a tradition especially in Sundanese society. Besides having high artistic value, bridal makeup has a symbolic prayer [18], [19]. According to Desiana argued that basically, character inherent in a culture will also shape the individual character. In this case, Sundanese siger makeup is a Sundanese culture character that belongs to the Sundanese society, which contains hope for harmonius married life [10], [20], [21].

\section{RESEARCH METHOD}

A qualitative method applied in this study with a descriptive approach. According to [22] The argued that qualitative research tries to understand the meaning of an event by trying to interact in the situation/phenomenon. Literature study and interview used in collecting the data in this study. Literary studies of several studies related to the research studies and interviews are from Sundanese bridal akeup artists. The Sundanese people are Sundanese people in Ciamis West Java, precisely in the district of Cihaurbeuti.

Discussing comprehensively from the research requires literature review and wider, deeper observation, so that the researchers limit the object of the research. The object of the research is the bride's makeup specifically makeup on their head. This is because the limitation of the research and the researchers hope that it can be a reference for further research that is more complex and deeper.

\section{RESULT AND DISCUSSION}

In this result and discussion, it will discuss the result that is limited by the meaning of the bridal makeup of Sundanese people, especially those are worn by brides on head accessories. Other things displayed are the results of the literature review and unstructured interviews to the interviewees as an addition to the result of the study.

\section{a. The Meaning of Sundanese Bride Makeup}

Some of the accessories worn by Sundanese bride are siger crown, betel leaves on the forehead, cape rates on the back of the bun, kembang goyang on the bun, strands of jasmine that fall to the body.

The siger crown is a hallmark of Sundanese brides. Siger is interpreted as a crown for jewelry on the bride's head [23]. Siger is a symbol for someone who does sacred ceremonies, such as 
marriage [24]. In addition, it can be interpreted as an honor, wisdom, and wise attitude as the main things need to be upheld. Siger is made of metal that is assembled in a circle. The front is used on the forehead and the back is at the back of the head. The meaning of the siger crown is hope of respect, wisdom, and wisdom in marriage [18]. Therefore, the crown that should be worn over the head has meaning and prayer contained as something sacred and must be upheld. The connection with the element of art is the siger crown makes the bride look more elegant and like a royal princess.

\section{b. Betel Leaves on the Forehead}

The Sundanese bride wore betel leaves on the forehead with diamind shapes. The use of betel leaves on the forehead is called diseureuhan. According to [10], the sound of the word seureuh or in Indonesian language is sirih (betel) is considered to be close to the sound of the word reureuh (rest). This means that a wife must be able to become pangreureuhan (rest area) of her husband and child later. Furthermore, it can be interpreted that a wife must be able to provide shade to her husband and children [25]. The use of betel leaves is also a symbol of repellent [10], [18]. From an artistic point of view, the diamond shape is symmetrical if it stored between the eyebrows or in the middle of the forehead.

\section{c. Cape Rates behind the Bun}

There are six cape rates like small butterflies behind the bun. It symbolizes the women's loyalty to her partner. This cape rates has a beautiful element of art as a perfetct flower.

\section{d. Kembang Goyang on the Bun}

There are seven kembang goyang on the bun with five pieces facing forwards, and two facing back. It has meaning that women must look beautiful like flowers both from the front and back, and beautiful from all sides. Kembang goyang is seen from the art value as an attractive headdress. It has its own beauty because its shape is always moving and it can be shaken.

\section{e. A Strand of Jasmine that Falls to the Body}

A string of jasmine taht falls to the body is called jasmine ronce. It symbolizes the purity and sanctity of a woman. This jasmine string consists of Mangle Pasung Jasmine, Mangle Susun, Mangle sisir, Penetep, Mayangsari [18].

"The Mangle used to decorate the bun has an aesthetic function. It aims to make the bride look more or become beautiful. The aesthetic function of using Mangle as a bun decoration is to beautify the appearance of the bride and also to scent the hair. Flower edits on the hair will make hair fragrant with a distinctive natural smell [25], [26].

\section{CONCLUSIONS}

Sundanese bridal makeup in the perspective of art education has the meaning of each decoration worn. It contains symbol of meaning, prayer, and positive expectations for the sustainability of the bride's household. There is a need for efforts to preserve Sundanese cosmetology culture by the community and the government. 


\section{ACKNOWLEDGMENTS}

The researchers thanked to all the parties concerned.

\section{REFERENCES}

[1] A. P. Nurhasan, "Kontribusi Hasil Kursus Tata Rias Pengantin Sunda Siger terhadap Kesiapan Menjadi Penata Rias Pengantin," Universitas Pendidikan Indonesia, 2014.

[2] A. Jornet and W. M. Roth, "Imagining design: Transitive and intransitive dimensions," Des. Stud., vol. 56, pp. 28-53, 2018.

[3] A. L. Greil, J. McQuillan, A. R. Burch, M. H. Lowry, S. M. Tiemeyer, and K. S. Slauson -Blevins, "Change in Motherhood Status and Fertility Problem Identification: Implications for Changes in Life Satisfaction," J. Marriage Fam., 2019.

[4] S. Syarbaini and Rusdiyanta, Dasar-Dasar Sosiologi. Yogyakarta: Graha Ilmu, 2009.

[5] B. Melim, M. Matias, T. Ferreira, and P. M. Matos, "Parent's and Children's Emotion Regulation and the Work-Family Interface," J. Marriage Fam., 2019.

[6] D. Andiyanto, Seri Kreasi Sanggul. Jakarta: PT. Gramedia Pustaka Utama, 2010.

[7] B. Wagner, "Health Status and Transitions in Cohabiting Relationships of American Young Adults," J. Marriage Fam., vol. 81, no. 4, pp. 847-862, 2019.

[8] Ismayanti, Pengantar Pariwisata. Jakarta: Grasindo, 2010.

[9] C. Zhang, V. L. Fong, H. Yoshikawa, N. Way, X. Chen, and Z. Lu, "The Rise of Maternal Grandmother Child Care in Urban Chinese Families," J. Marriage Fam., p. jomf.12598, 2019.

[10] F. I. Desiana and R. D. Dienaputra, "THE ACCULTURATION OF MODERN SUNDA SIGER COSMETIC TO JAPANESE IGARI MAKEUP,” Patanjala, vol. 11, no. 1, pp. 149-164, 2019.

[11] D. C. Semenza, K. A. Roof, L. James-Hawkins, Y. F. Cheong, R. T. Naved, and K. M. Yount, "Gender-Equitable Parental Decision Making and Intimate Partner Violence Perpetration in Bangladesh,” J. Marriage Fam., vol. 81, no. 4, pp. 920-935, 2019.

[12] A. S. S. Ningtyas, "REPRESENTASI BUDAYA TATA RIAS PENGANTIN MALANG KEPUTREN DAN MALANG KEPRABON," e-Journal, vol. 02, no. 3, pp. 38-49, 2013.

[13] D. P. Lindstrom, M. M. Liu, and C. Jira, "The Role of Parents and Family Networks in Adolescent Health-Seeking in Ethiopia," J. Marriage Fam., vol. 81, no. 4, pp. 830-846, 2019.

[14] Y. Pebrianti, "Tinjauan tentang Tata Rias Pengantin Koto Nan Gadang di Kota Payakumbuh,” Universitas Negeri Padang, 2017.

[15] F. Ceschin and I. Gaziulusoy, "Evolution of design for sustainability: From product design to design for system innovations and transitions," Des. Stud., vol. 47, pp. 118 $163,2016$.

[16] A. Liliweri, Makna Budaya dalam Komunikasi Antarbudaya. Yogyakarta: LkiS, 2007.

[17] H. Choi, B. Nam, S. Kim, and C. Park, "Contact with Parents and Parents -in -Law, Gender, and Marital Satisfaction in Korea," J. Marriage Fam., 2019.

[18] N. Kristiana and Marlina, "Manfaat Hasil Pelatihan Tata Rias Pengantin Sunda Puteri Sebagai Kesiapan Uji Kompetensi Rias Pengantin,” Fesyen Perspekt., vol. 6, no. 1, pp. 44-55, 2016.

[19] J. A. Behrman, "Polygynous Unions and Intimate Partner Violence in Nigeria: An Examination of the Role of Selection," J. Marriage Fam., vol. 81, no. 4, pp. 905-919, 2019. 
[20] K. J. Eickmeyer, W. D. Manning, and S. L. Brown, "What's Mine Is Ours? Income Pooling in American Families," J. Marriage Fam., vol. 81, no. 4, pp. 968-978, 2019.

[21] K. Shroyer, T. Lovins, J. Turns, M. E. Cardella, and C. J. Atman, "Timescales and ideaspace: An examination of idea generation in design practice," Des. Stud., vol. 57, pp. 9-36, 2018.

[22] M. Yusuf, Metode Penelitian Kuantitatif, Kualitatif \& Penelitian Gabungan. Jakarta: Kencana, 2017.

[23] R. . Danadibrata, Kamus Basa Sunda. Bandung: PT. Kiblat Buku Utama, 2009.

[24] T. Santoso, Tata Rias \& Busana Pengantin Seluruh Indonesia. Jakarta: Gramedia Pustaka Utama, 2010.

[25] Wibisana, Arti Perlambang dan Fungsi Tata Rias Pengantin dalam Menanamkan Nilainilai Budaya Daerah Jawa Barat. Jakarta: Departemen Pendidikan dan Kebudayaan Proyek Inventarisasi dan Dokumentasi Kebudayaan Daerah, 1986.

[26] K. Dorst, "Creativity in the design process: co-evolution of problem-solution," Studies, vol. 17 , no. 4, pp. 341-361, 1996. 